\title{
A Desktop Study to Determine Mineralization Using Lineament Density Analysis at Kulon Progo Mountains, Yogyakarta and Central Java Province, Indonesia
}

\author{
Okki Verdiansyah ${ }^{*}$ \\ Program Studi Teknik Geologi - Institut Teknologi Nasional Yogyakarta, Indonesia
}

Received: 2018-10-19

Accepted: 2019-04-04

Keywords:

mineralization;

gold;

lineament;

volcano;

GIS;

Yogyakarta.

\begin{abstract}
A geological study was conducted in Kulon Progo and its surrounding areas (Kulon Progo and Purworejo Regency). It focused on regional geology, tectonic configuration, geodynamics and magmatism, lithology and volcanology, and mineralization. Although there has been considerable research of mineralization in the area-particularly in Kokap (Kulon Progo Regency), Bagelen (Purworejo Regency) and Gupit (Magelang Regency), the potential of precious metals has not been determined due to data limitations. The study combined qualitative and semi-quantitative methods using a desktop geologic analysis, which facilitates lithology interpretation, volcanic boundary system, and lineament density assessment. The geology of the region is composed of an ancient volcanic complex of the Old Andesite Formation formed during the Late Oligocene-Miocene, and the mineralization in Kokap, Bagelen, and Gupit is epithermal. Based on the analysis results, the mineralization occurs in the central to proximal facies of the paleo-volcano, and the system ranges from 2.2 to $3.8 \mathrm{~km}$ in diameter. The manual analysis of the lineament density showed that the main direction of the lineaments was SE-NW with a maximum density of $2025.9 \mathrm{~m} / \mathrm{km} 2$ and an anomaly limit of $>1800 \mathrm{~m} / \mathrm{km} 2$. In the combined semi-automatic analysis, the maximum density was $8.3 \mathrm{~km} / \mathrm{km} 2$. The target area of mineralization included four anomalous areas, namely Bagelen-Kokap, Salaman, Kaligesing, and Loano, associated with the central and proximal facies of each small paleo-volcano.
\end{abstract}

Corespondent Email: okki.verdiansyah@sttnas.ac.id
(C) 2019 by the authors. Licensee Indonesian Journal of Geography, Indonesia.

This article is an open access article distributed under the terms and conditions of the Creative Commons

Attribution(CC BY NC) licensehttps://creativecommons.org/licenses/by-nc/4.0

\section{Introduction}

The study of Lineament Density Analysis (LDA) was conducted in Kulon Progo Mountain and the surrounding areas, i.e., Purworejo Regency (Central Java Province) and Kulon Progo Regency (the Special Region of Yogyakarta) (Figure 1). This region is located approximately $40 \mathrm{~km}$ west of Yogyakarta City. It is an elevated landscape with N-S orientation and has a rough surface shaped by eroded Tertiary rocks.

There have been numerous studies focusing on the geologic features of Kulon Progo Mountain and its surrounding areas, e.g., regional geology (Rahardjo et al., 1995), tectonic configuration (Syafri et al., 2013; Widagdo et al., 2018), geodynamics and magmatism (Smyth et al., 2008; Maryono et al., 2012), lithology and volcanoes (Harjanto, 2011; Bronto, 2013), and the presence of alteration-mineralization (Harjanto et al., 2006, 2009, Idrus et al., 2013, 2014; Pramumijoyo et al., 2017; Prasetyo et al., 2017; Pambudi et al., 2018). Furthermore, research related to precious metal mineralization in Kulon Progo has been carried out in several regions, namely Kokap (Kulon Progo Regency), Bagelen (Purworejo Regency), and Menoreh (Magelang Regency), and revealed the presence of hydrothermal systems. However, the potential of precious metals is difficult to assess due to lack of data.
A preliminary regional review is still urgently needed to identify the potential of mineralization based on more precise parameters, such as the concept of volcanology and magmatism concerning mineralization, morphological features, and lineament density. In this study, the mineralization potential was evaluated using studio analysis by integrating some parameters, namely lithology interpretation, boundary system, and lineament density. This study is expected to generate an initial picture of the mineralization potential of the known areas and unanalyzed regions for the target of further research or case studies.

Indonesia is part of the Southeast Asian tectonic setting formed in the Cenozoic Era. This setting regulates the magmatism and volcanic arc corridor associated with mineralization during the Tertiary Period (i.e., Oligocene-Pliocene Epoch), as identified in the Sunda-Banda tectonic belts. Because the evolution of magmatism during the Paleocene-Eocene Epoch in Java Island is still uncertain, the pattern of magmatism can be observed from Oligocene (Setijadji et al., 2006; Maryono et al., 2012; Setijadji and Maryono, 2012). The magmatism in Kulon Progo involves a calc-alkaline magma series with basaltic and andesitic-dacitic compositions, which occurred in two periods, namely 


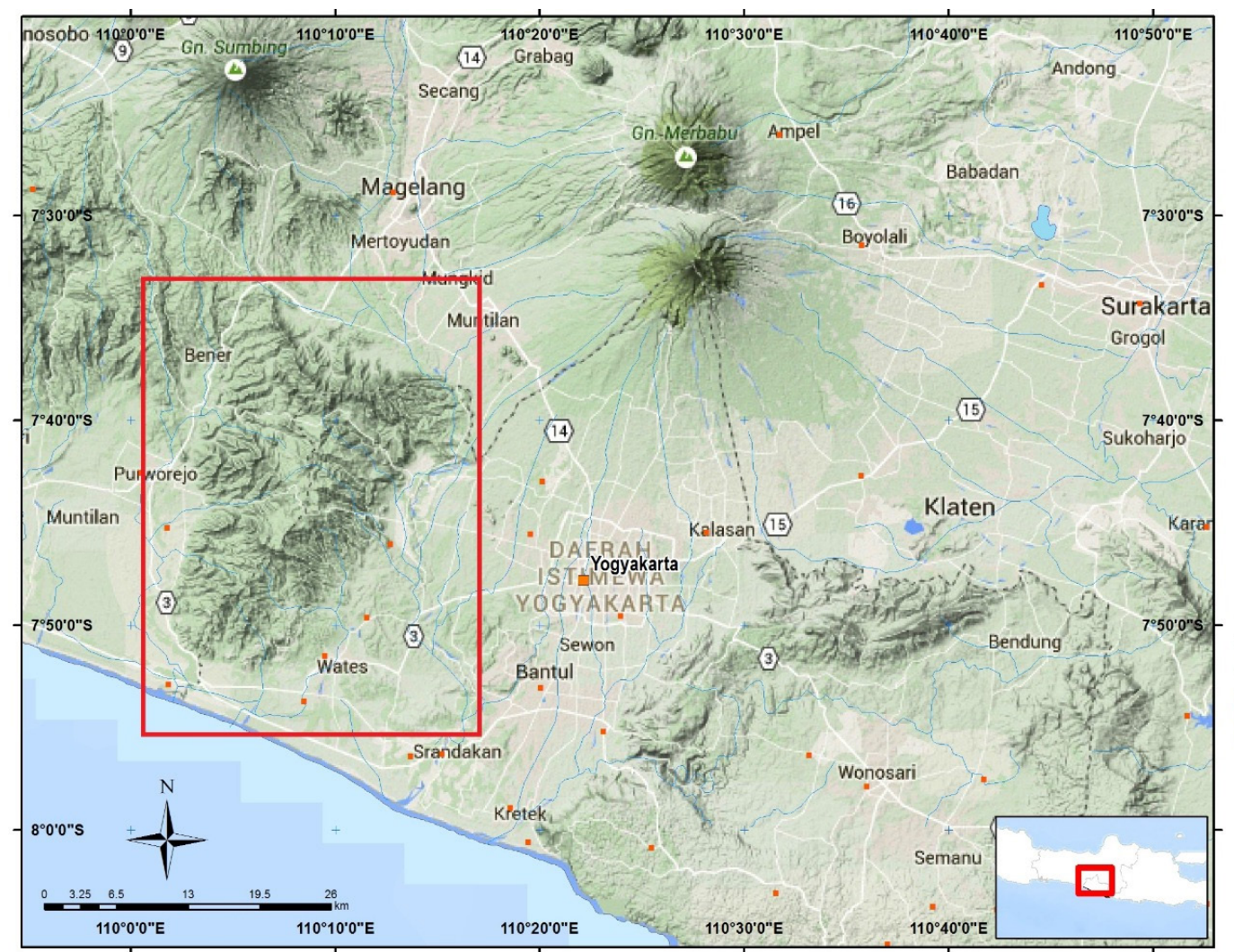

Figure 1. The research location and the boundary for lineament analysis.
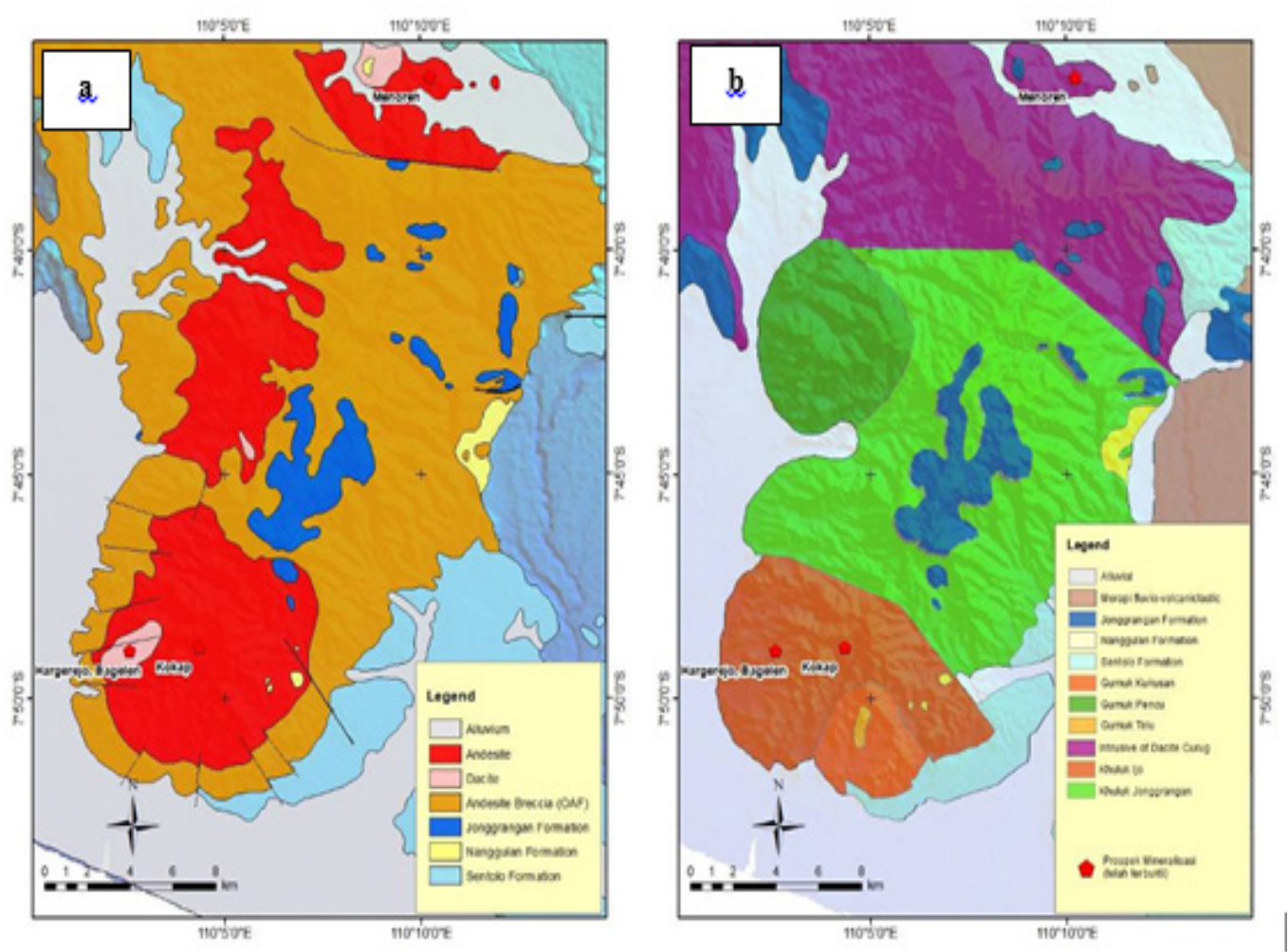

Figure 2. (a) The simplified regional geological map of Kulon Progo region (Rahardjo et al., 1995) and (b) The volcanic-stratigraphic map of Kulon Progo area (Harjanto, 2011) and the occurrences of epithermal mineralization (red circles). 
the Late Oligocene-Early Miocene (25.4-29.6 Ma) and the Late Miocene (8.1 $\pm 1.19 \mathrm{Ma})$ (Harjanto, 2011).

The geology of the study area is inseparable from magmatism, volcanism, and sedimentation in the Southern Mountains. Most of the Southern Mountains are volcanic complexes that form gumuk (single volcanoes), khuluk (a group of volcanoes), and bregada (a caldera complex), as well as some ancient calderas (Hartono, 2010). The age of the igneous rock in the volcanic complex ranges from Oligocene to Miocene, which on the regional geological map referred to as the Old Andesite Formation or OAF (west side of the map; covering areas such as Kulon Progo and Godean) and Mandalika (east side). The magmatism that shapes mineralization in the Southern Mountain is probably at the age of 11.3-17.2 Ma, e.g., in Gajahmungkur (Wonogiri), Mount Ijo (Kulon Progo), and Menoreh (Magelang). It is accompanied by the phase of mineralization of the facies in the central eruption.

Rahardjo et al. (1995) have depicted the regional geology of the study area in the quadrangle of the Yogyakarta geological map (Figure 2a). The oldest rock (Eocene) is included in Nanggulan Fm (Teon), which is composed of lignite layers, sandy marls, claystone with limonite concretions, interlayers of marl and limestone, sandstone, and tuff. Kebobutak Fm (Tmok), underlying the areas in Bayat District, is composed of andesitic breccia, tuff, lapilli-tuff, agglomerates, and andesite lava flows of Oligocene-Miocene age. These two formations are intruded by diorite $(\mathrm{dr})$ and andesite (a) of Lower Miocene age. Volcanism occurred between the Oligocene and Miocene Epoch and formed the Old Andesite Formation, i.e., lava, intrusion, and volcaniclastic rocks (andesitic breccia).

The geological structure of the Paleogene-aged rocks, especially in the east of Kulon Progo region, appears to form a parallelogram pattern-i.e., a combination of the W-E and N-S structures that make up the Yogyakarta-Bantul Graben (Barianto et al., 2010). The S-NW to S-NE structures (Syafri et al., 2013) and the SE-NW structure Gadjah Mountain (Widagdo et al., 2018) control the domain of the tectonic patterns in Kulon Progo. In Menoreh Mountain, there is a W-E orientation that partly controls the direction of the morphology in the northern part of the area.

Paleo-volcanism Harjanto (2011) has divided Kulon Progo into three khuluk (groups of volcanoes) and two gumuk (single volcanoes). The gumuk is interpreted as the parasitic cones of the main khuluk. The three khuluk are Khuluk Ijo, Jonggrangan, and Sigabug, while the two gumuk are Gumuk Kukusan and Gumuk Pencu. There are two intrusions in both gumuk, namely Telu (microdiorite) and Curug (dacite). The magmatism process in Kulon Progo took placed in two periods, namely (1) during the Late OligoceneEarly Miocene $(29.63 \pm 22.64 \mathrm{Ma})$ (Soeria-Atmadja et al., 1994), producing microdiorite, andesite, and dacite, and (2) the Late Miocene (8.1011 $\pm 1.19 \mathrm{Ma})$, involving the intrusion of diorite (Telug and Curug) (SoeriaAtmadja et al., 1994).

When a hydrothermal system appears on the surface, it may indicate the presence of other hydrothermal systems both on the surface and in the subsurface. Igneous rocks with specific texture and minerals likely produce fairly good mineral deposits, provided that other factors support sedimentary rocks to penetrate or exist in the hydrothermal system.

The hydrothermal system in Kulon Progo is mainly epithermal (Ansori and Hastria, 2013; Idrus et al., 2013, 2014; Pramumijoyo et al., 2017; Pambudi et al., 2018), and some are hypothetically related to porphyry below the surface (Prasetyo et al., 2017). The types of mineralization are low- to intermediate-sulfidation epithermal in Kokap, epithermal in the form of Lithocaps in Bagelen, and high-sulfidation epithermal in Gunung Gupit (Salaman, Magelang). Pambudi et al. (2018) state that in Kokap (Sangon District, Kulon Progo) the mineralization is low-sulfidation epithermal with gold veins developing in the andesitic unit of the Old Andesite Formation. Mineralization occurs as veins containing native gold (free gold associated with chalcopyrite, pyrite, arsenopyrite, and sphalerite) that is surrounded by argillic, advanced argillic, inner propylitic, and propylitic alteration. The orientation of the veins follows SW-NW pattern, and a minor amount of them has W-SW pattern. This mineralization is controlled by the fault zone, the product of tectonic activities in Kulon Progo Mountains. Its economic prospect was drilled and tested by a state-owned company (PT. Antam, Tbk) from early 2003 to 2005. However, these activities are ceased because the work permit has ended. Pramumijoyo et al. (2017) point out that the prospective low sulfidation epithermal in Kokap is controlled by the structures developing in the andesitic unit. Its formation is controlled by the tension fractures (NW-SE and NE-SW), which are associated with sinistral strike-slip faults (NE-SW), dilational jog (NNW-SSE), oblique normal fault (WNW-ESE), and predictable normal fault at the northeast of the study area (NW-SE). The mineralization of gold in the quartz veins (quartz-adularia-sericite) forms at $242.1-257.6{ }^{\circ} \mathrm{C}$ and salinity of $1.57-3.87$ wt. $\% \mathrm{NaCl}$ equivalent. Also, some mineralization is distributed in the alteration zones.

The high-sulfidation epithermal was detected in Bagelen or Gunung Agung area, Purworejo; it is associated with intrusion in the subsurface (Ansori and Hastria, 2013; Prasetyo et al., 2017) and in Gupit Mountain (Menoreh), Salaman, Magelang (Idrus et al., 2013). Typically, the alteration occurs as silicification and advanced argillic and argillic alteration that is followed by the formation of stockworks. Some samples have high grades up to $42.4 \mathrm{ppm} \mathrm{Au}$ (Idrus et al., 2013), but most of them have a low grade or barren. Bagelen has Molybdenite minerals and some copper 


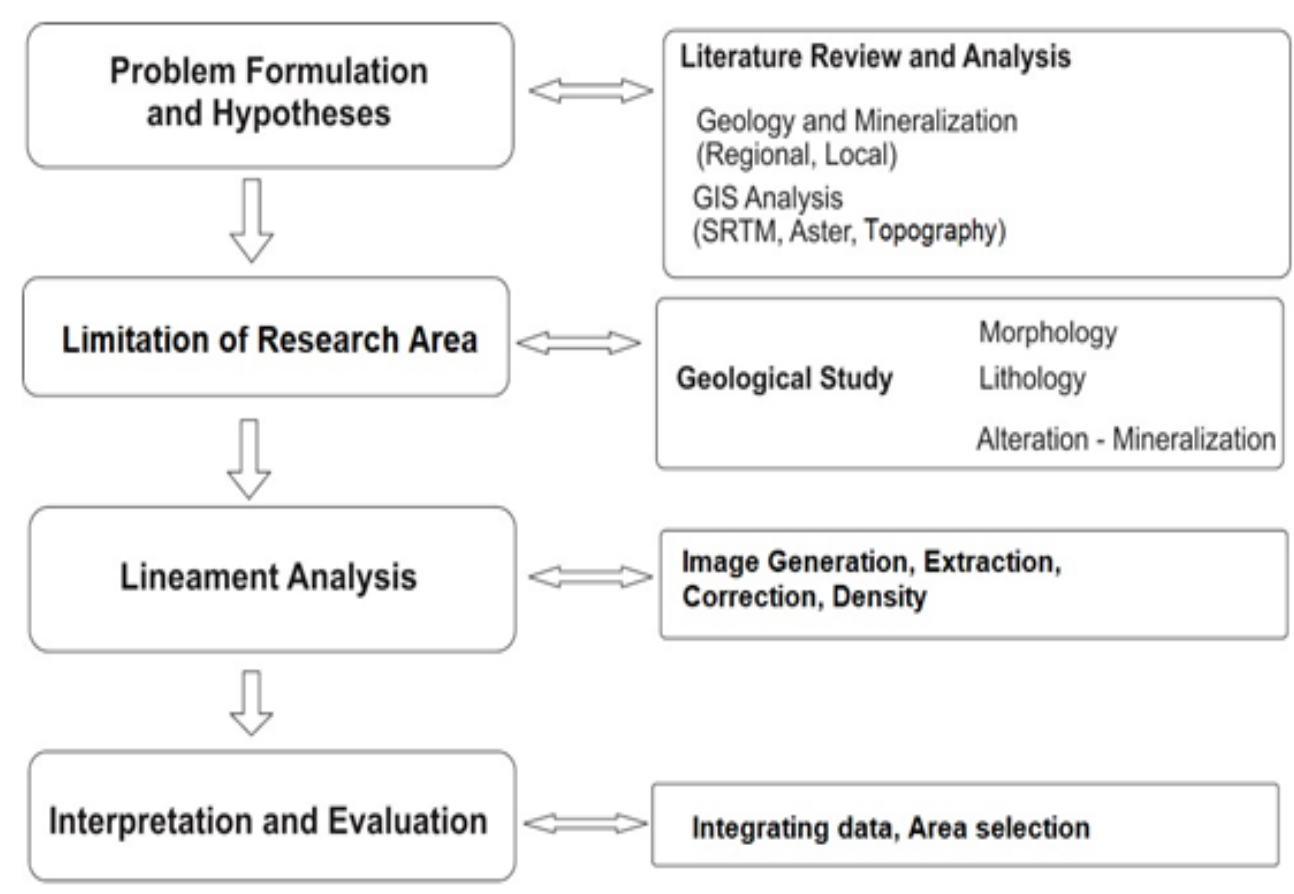

Figure 3. The flowchart of the research stages

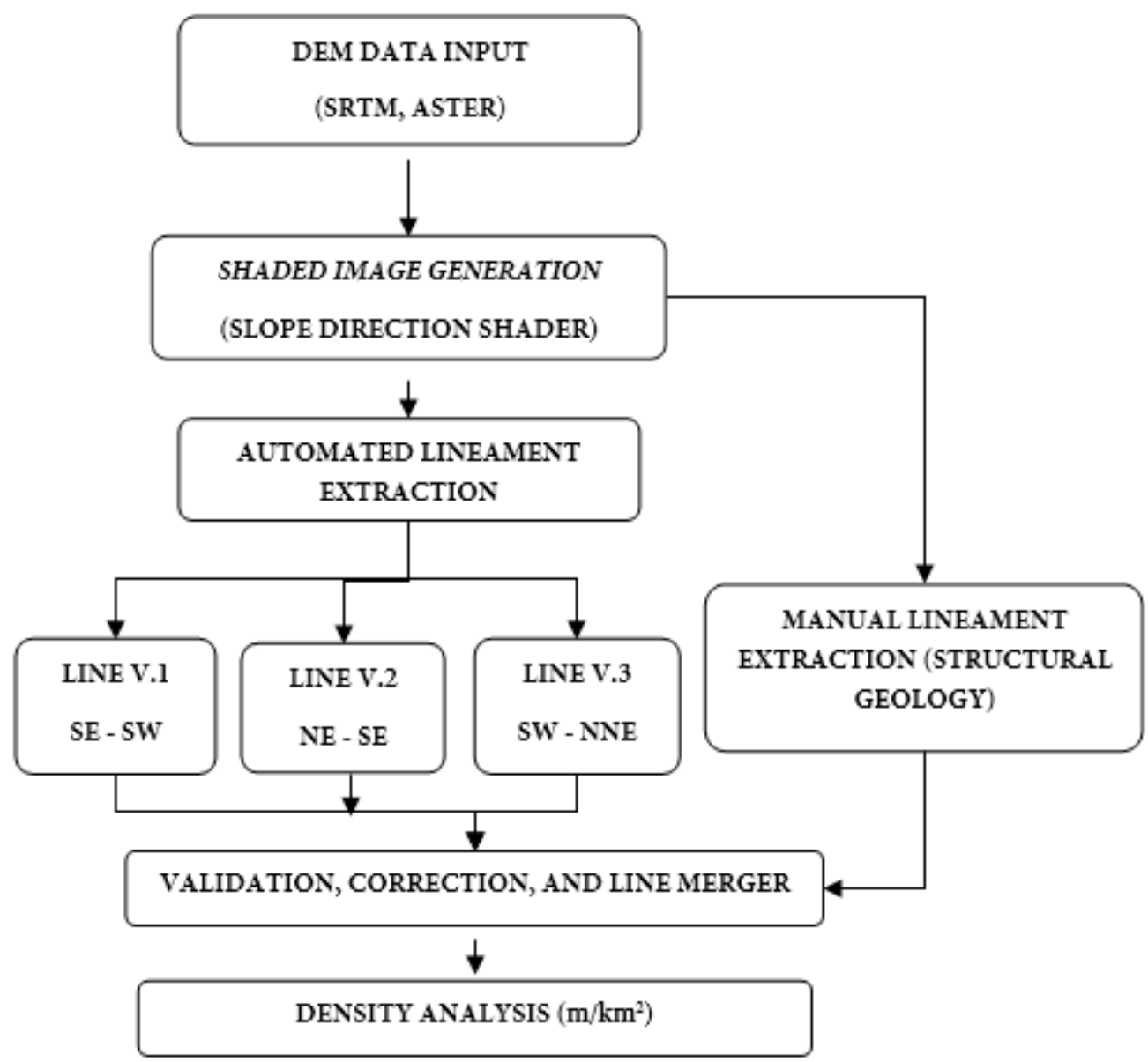

Figure 4. The stages of Lineament Density Analysis (LDA) conducted in this study. 
sulfide, both of which are interpreted as the product of high temperatures, such as in the case of intrusion (Prasetyo et al., 2017). The high-sulfidation epithermal mineralization is developed in the andesitic unit and controlled by the NE-SW strike-slip fault (Idrus et al., 2013).

\section{Methods}

The research used a combination of qualitative and semi-quantitative methods by identifying the value of

Table 1 . The values of the parameters used in lineament extraction in PCI-Geomatics 2017 software, adapted from Abdullah et al. (2010).

\begin{tabular}{lll}
\hline Name & Description & Values \\
\hline RADI & The radius of the filter in pixels & 12 \\
GTHR & The threshold for edge gradient & 90 \\
LTHR & The threshold for curve length & 30 \\
FTHR & The threshold for line fitting error & 10 \\
ATHR & The threshold for the angular & 30 \\
& difference & \\
DTHR & The threshold for linking distance & 20 \\
\hline
\end{tabular}

the zone with high lineament density. These processes were conducted semi-automatically, i.e., combining computer software and qualitative interpretation with other related geological data as a reference. The computer software included Global Mapper 12, PCIGeomatica 2018, QGIS Bonn 3.23, ArcGIS 10.3, and Microsoft Office 2013 for data rearrangement.

This study also used secondary data: [1] Database of regional geology maps and volcanic-stratigraphic map, [2] The presence of mineralization identified by previous researchers, and [3] DEM data obtained from 30m-resolution ASTER images and 90m-resolution SRTM images. The desktop analysis in this process was then supplemented with field data from the reconnaissance survey by following the steps listed in Figure 3.

\section{Lineament Density Analysis}

The lineament analysis was carried out for various purposes and themes, especially for structure-related morphology study. In Indonesia, the method and use of lineament have been developed for, one of which, the extraction of morphologic lineament in karst (Haryono et al., 2016), and a large graben area to determine the potential of earthquakes (Hadi, 2010). Lineament Density Analysis (LDA) is an advanced

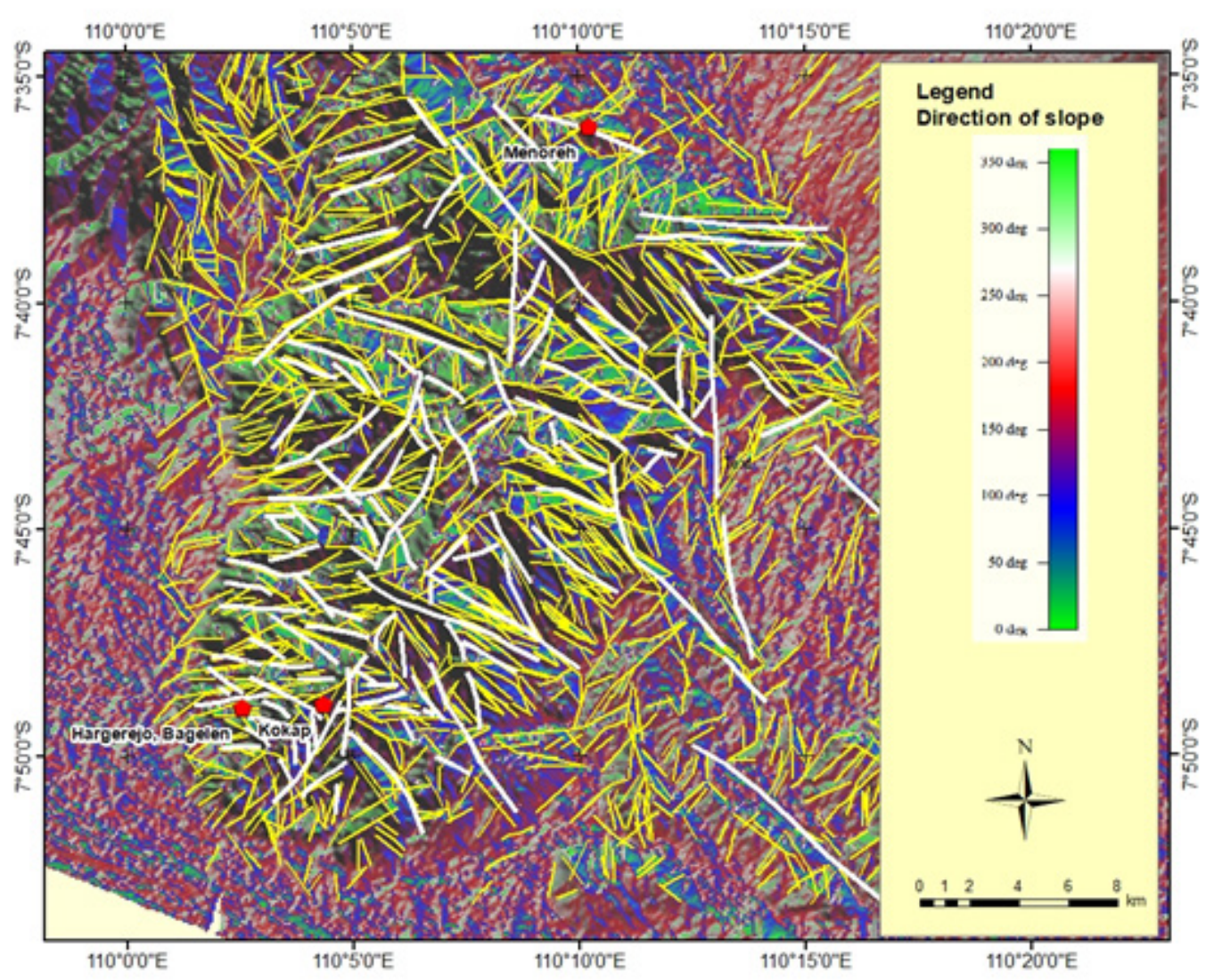

Figure 5. The lineament map of research area and the slope direction shading image as background. This map represents two methods of lineament production: automatic extraction (yellow lines) and manual identification of lineament (white lines) based on the concept of geological structure. 
spatial processing that can be used for various purposes, especially structural studies (Abdullah et al., 2010; Thannoun, 2013), the delineation of the remaining morphological system of calderas (Verdiansyah, 2017), and the assessment of the prospect of mineralization (Hubbard et al., 2012; Verdiansyah, 2015). The most important factor to consider while performing LDA is the quality or resolution of the basemap, which comes in the form of Digital Elevation Model (DEM). High-resolution images are preferable, such as IFSAR DEM with $5 \mathrm{~m}$ resolution, SRTM with 30 and $90 \mathrm{~m}$ resolution, and ASTER with $30 \mathrm{~m}$ resolution, or detailed topographic data that is first processed into DEM. DEM data has a better resolution than satellite imagery, making it suitable for geological analysis. "Lineament" is defined as the appearance of straightness on a linear surface that can be mapped, such as fault lines, creases, or crack lines, as a result of certain geological events (Leary et al., 1976). This study used the concept proposed by Thannoun (2013) with some modifications (Figure 4).
Here is the description of each stage:

1) Data Input: DEM is a digital elevation data that describes the expression of surface topography in an area, which can be extracted into topographic data-slope, aspect, and shaded relief-using computer algorithms. DEM data represents the exact conditions without distortion using particular variations, such as altitude and angle direction, and it has better resolution than satellite imagery (Batson et al., 1975). The DEM data in this study was obtained from 90m-resolution SRTM and $30 \mathrm{~m}$-resolution ASTER images. It was used in the analysis of geological structure, the pattern of rock distribution, and the pattern of straightness (lineament).

2) Image Generation (Slope Direction Shading, using Global Mapper software). In this process, images are generated from automatic analysis of slope direction from DEM data. The slope directional shading is assumed as a real condition of topographic or relief in research area. This method is faster and simpler than conventional method such as using several directional lighting of topographic shading. This image processing

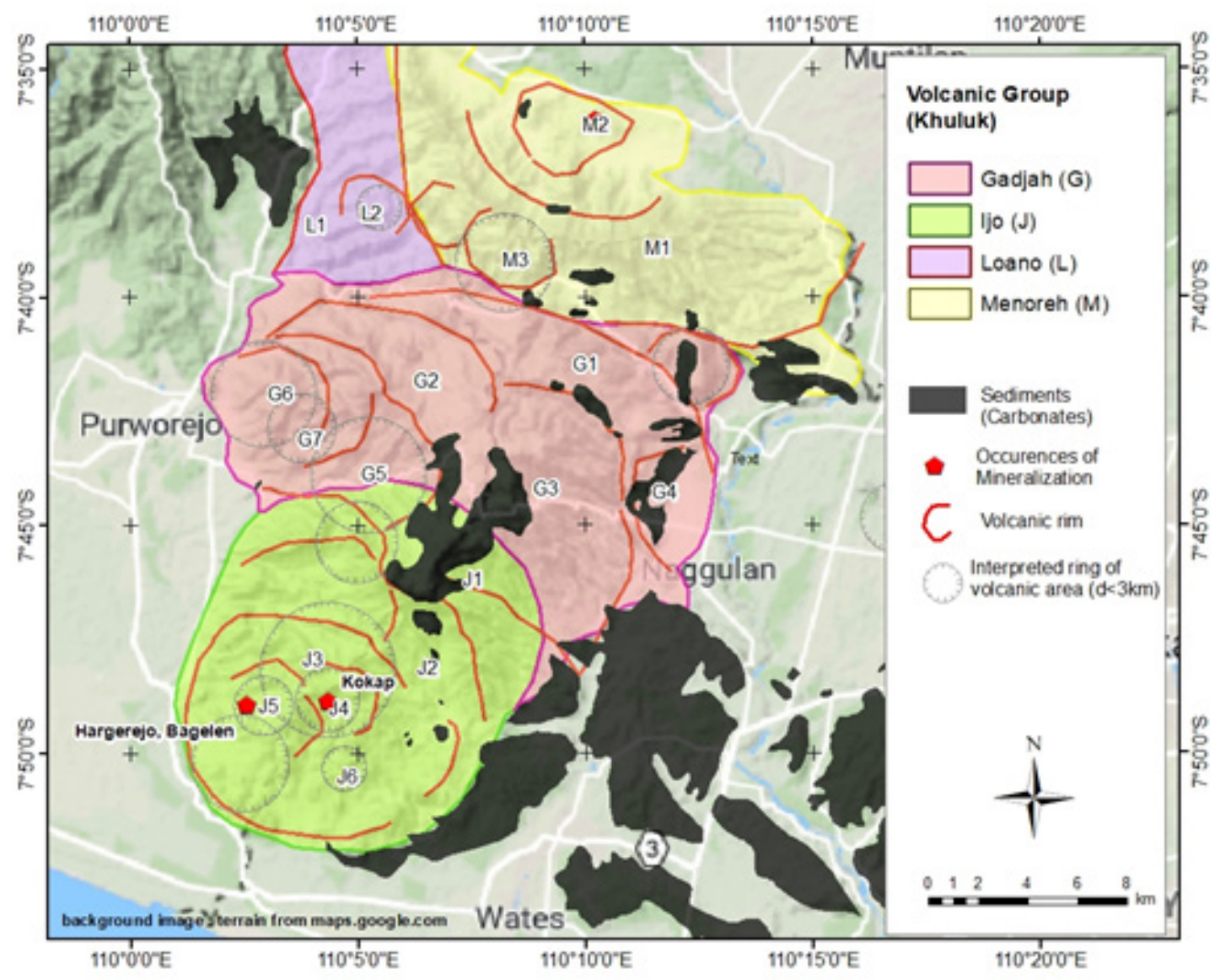

Figure 6. The interpretation of the volcanic system, which shows the boundary (rim) of the four volcanic groups (khuluk): M (Menoreh), G (Gadjah), J (Ijo), and Loano (L). The order of the relative age was interpreted based on the sequence of volcanic rims, e.g., J5 is the fifth order of the volcanic center in Khuluk Ijo. 

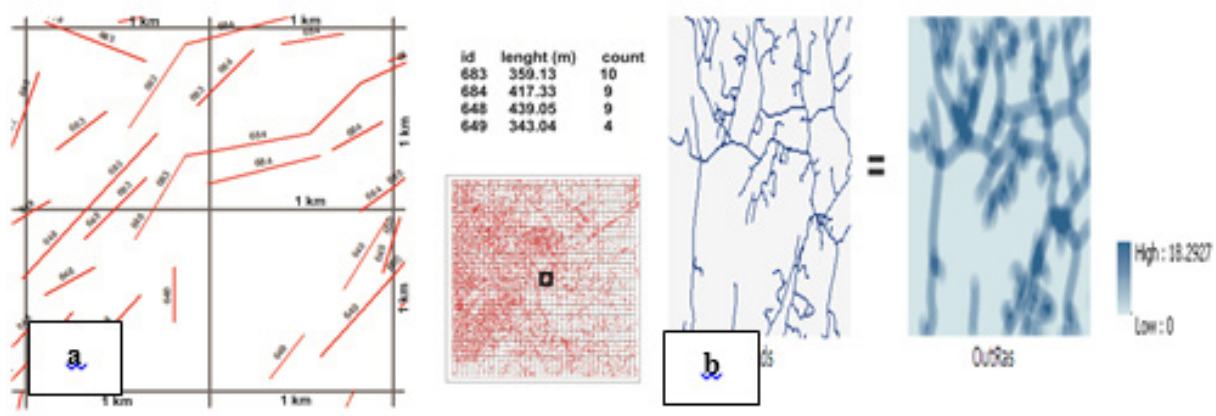

Figure 7. The concept of density calculation: (a) manual and (b) automatic in ArcGIS.

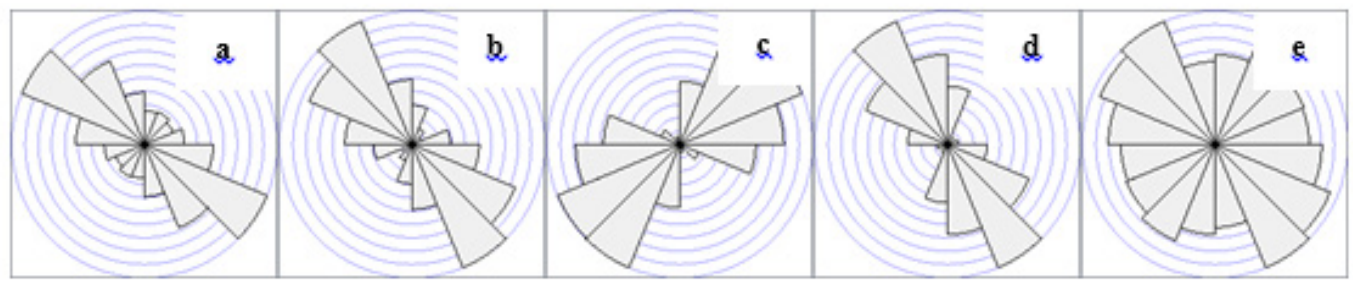

Figure 8. Rose diagrams showing the main direction of the lineaments: (a) based on manual structure, (b) extraction of v1 (slope direction= SE-SW), (c) extraction of v2 (slope direction= SW-NNE), (d) extraction of $\mathrm{v} 3$ (slope direction= NNE-SE), and (e) the overall combination of slopes.

produced an RGB image representing a gradual slope direction between $0^{\circ}-360^{\circ}$ (Figure 5)

3) Extraction (Automatic): The lineament was obtained automatically using PCI Geomatica software. The extraction process (Line Extraction) used the [LINE] algorithm on PCI Geomatica by entering the parameters proposed in Abdullah et al. (2010) (Table 1).

4) Extraction (Manual): The lineament was obtained by observing the pattern of straightness in the direction of shading based on the concept of geological structure. The results of this process were then evaluated with the output of the automatic extraction.

\section{Result and Discussion}

The desktop study or studio analysis produced several interpretations in the forms of a volcanic rim, volcaniclastics distribution, and lineament pattern and density. These results were adjusted to the data proven by previous researches, such as in Kokap, Bagelen and Menoreh. These results obtained using qualitative analysis, as the basis for determining the targets of valuable mineral deposits exploration in Kulon Progo Mountains.

\section{Interpretation of Volcanic System}

Based on existing geological and morphological patterns and approaches, qualitative contour boundaries can be generated by considering the existing geological concepts. The analysis found that the mineralization was in the center to the proximal center of the eruption with the diameter of the volcanic linkage ranging between 2.2 and $3.8 \mathrm{~km}$. In these areas, Kokap and Bagelen are formed on adjacent volcanic systems at the center of the 4th and 5th prehistoric volcanic compounds in Mount Ijo (Figure 6). As for the prospect of mineral exploration in Menoreh, the mineralization is formed in a single volcano system in the second period of the Menoreh complex in the lithology of coherent rocks that are widely separated and, therefore, developed into high sulfidation (Idrus et al., 2013).

Based on the results of the secondary data analysis, mineralization occurred in the later regime of volcanoes and became part of a bigger volcano complex that had been formed previously. The qualitative estimates showed that the volcanism system also enabled the occurrence of mineralization in part of Khuluk Ijo (i.e., the rim J3 and J6) and the complex of Gunung Gadjah (i.e., at Khuluk Pencu; the rim G5, G7, and G8).

\section{Lineament Density}

The lineament density analysis used 1,573 lines (121 of which were identified manually) and 1,452 automatically extracted lineaments (consisting of 341 lines on v1, 696 lines on v2, and 415 lines on v3). It calculates the total length of lineaments (in meter) in a $1 \times 1 \mathrm{~km} 2$ grid (Figure 7a; Verdiansyah, 2017). This analysis can also be obtained automatically using the tools Line Density in Arc GIS, which is faster and more effective than manual density calculation; hence, the study used this feature (Figure $7 \mathrm{~b}$ ).

The Line Density Analysis in Kulon Progo was based on three (3) main parameters, namely:

1) The density of the manually extracted lineaments was identified to interpret the major geological structures. The main direction of the lineaments 


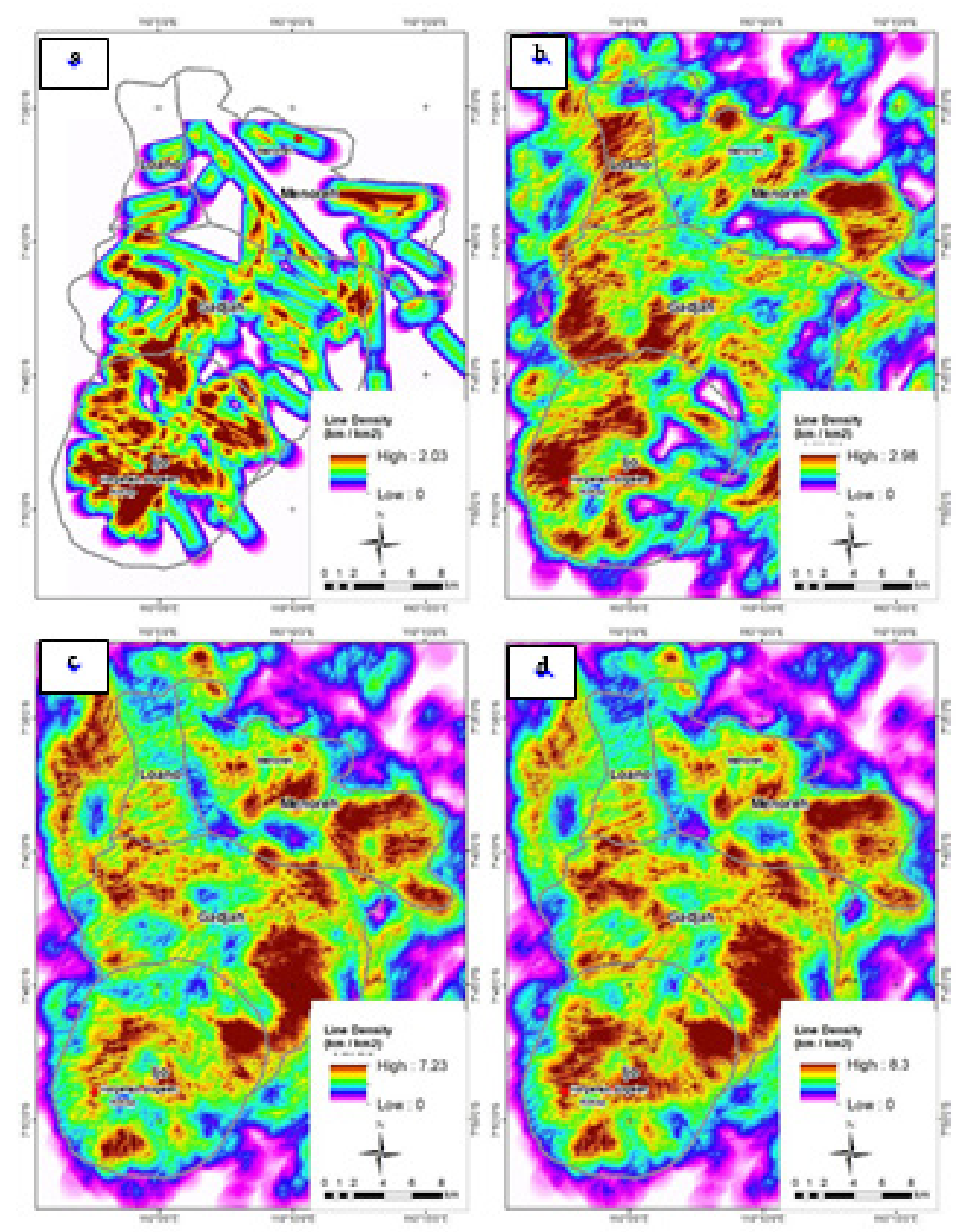

Figure 9. The map of lineament isodensity in Kulon Progo and its surrounding areas: (a) based on the parameters of the manual structural lineament, (b) based on the lineament extraction of $\mathrm{v} 2$, (c) based on the total automatic lineament extraction (v1, v2, and v3), (d) based on the total lineament (manual and automatic extraction).

is SE-NW (Figure 8a). The zone of maximum lineament density was $2025.9 \mathrm{~m} / \mathrm{km} 2$ (Figure 9a) the limit of density anomaly was estimated to be $1800 \mathrm{~m} / \mathrm{km} 2$. In this analysis, high anomalies were found in Khuluk Ijo and the west side of Gadjah Mountain or Khuluk Jonggrangan (particularly on Gumuk Pencu).

2) The density of the automatically extracted lineament. In this process, the extraction was automatically adjusted to the color hue formed in the image produced in the shading of slope direction. The directions of the lineaments are presented in Figure $8 \mathrm{~b}-\mathrm{d}$. For example, the SW-NNE lineaments on $\mathrm{v} 2$ that were extracted automatically and manually had similar density, i.e., with a maximum density of $2979.6 \mathrm{~m} / \mathrm{km} 2$ and estimated anomalies of greater than $1800 \mathrm{~m} / \mathrm{km} 2$. In the automatic analysis, the obtained zone of anomaly was more diffuse because the subjectivity factor was very limited. The zones of line density anomaly were detected in the center and west of Khuluk Ijo, the west side of Khuluk Gajah or Khuluk Jonggrangan (particularly on Gumuk Pencu), and the outer part of the western area between Khuluk Jonggrangan (Gunung Gadjah) and Menoreh Mountain.

3) The bulk density, it use combined parameters from all directions. In this combination, the maximum density was $8.3 \mathrm{~km} / \mathrm{km} 2$, considerably higher than the two previous parameters. The main direction of the lineaments was NW-SE or similar to parameter in point 1 . However, lineaments with other directions were more evenly distributed (Figure 8e). The zones of line density obtained with this parameter were distributed evenly throughout 

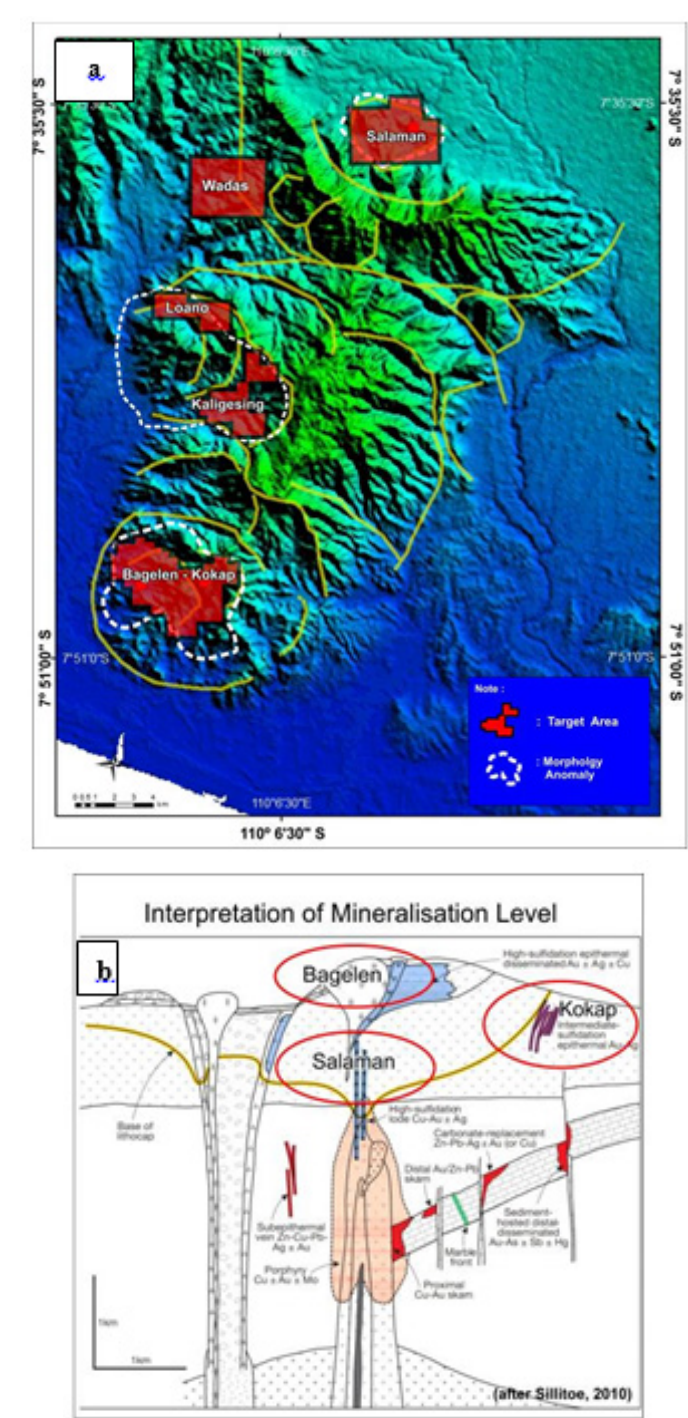

Figure 10. (a) The interpretation of interesting mineralization targets in Kulon Progo Mountain. (b)The position and interpretation of type of mineralization with the porphyry model, an approach proposed by Sillitoe (2010)

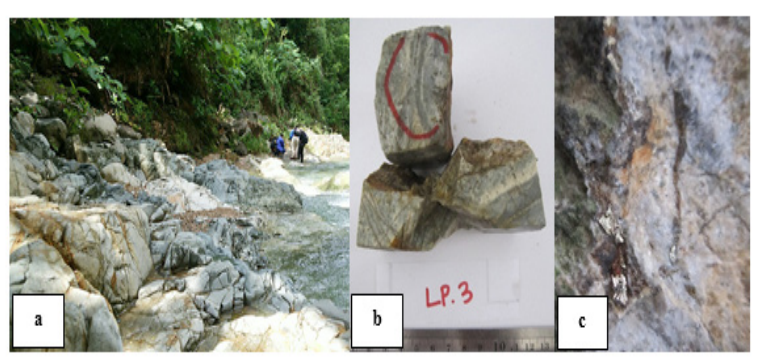

Figure 11. The indications of mineralization in Kaligesing, found in Sumbersari Hamlet: (a) a highly fractured rock and lineation of tectonics joint and micro-fault in dioritic units. This rock was altered and mineralized to porphyry type and locally overprinted by epithermal veins. (b) the sample of mineralized rock with abundant quartz veins, and (c) chalcopyrite that fills fractures and veins in sericitic alteration.
Kulon Progo (Figure 9c) with the broadest zone of anomaly located in Khuluk Ijo (J1) and Mount Gadjah East in G3 and G4 (see Figure 6) and spread to Khuluk Ijo (J3, J4, J5), the west side of Gadjah Mountain (G6, G7, X), and Menoreh Mountain (M2).

\section{Determination of Mineralization Area}

In the interpretation, the density parameters obtained from the manual and automatic lineament extractions were overlaid with geological parameters, namely center of the eruption, volcanism phase, and type of regional lithology. Anomaly readings were conducted qualitatively based on the pattern formed in areas of mineralization.

In epithermal cases, density anomalies are likely found in clusters of high density with a width of 1-2 km, which is similar to the results of the LDA in Cikotok, Pongkor, and Bengkulu (Verdiansyah, 2015). The physiography of Kulon Progo Mountains is characterized by a former ancient volcanic complex that extends north-northeast. The rest of this volcanic landscape is composed mainly of coherent rocks, such as andesitic lava, andesite, dacite intrusion, and pyroclastic and volcaniclastic rocks belonging to the Old Andesite Formation (OAF). Therefore, there is a possibility that the type of mineralization formed in the area is still in epithermal position, and that the character of the anomalous mineralization is found as a cluster or high-lineament density cluster.

The estimated areas of mineralization were generated from the overlay of the anomalous data and the geological anomaly. There are five anomalous regions, namely (1) Bagelen-Kokap, (2) Salaman, (3) Kaligesing, (4) Loano, and (5) Wadas (Figure 10a). These areas of mineralization are formed at the later eruption center and associated with the central and proximal facies of each gumuk. The characteristics of the mineralization were interpreted as related to low to high epithermal sulfidation with an association of $\mathrm{Cu}$ Au porphyry below their surface (Figure 10b).

\section{Geological Reconnaissance Survey}

After the targets of the areas of mineralization were obtained, the research continued with ground checking using geological reconnaissance survey. The survey was conducted in all target areas, except BagelenKokap and Salaman where the presence of epithermal mineralization had been proven scientifically. For these two areas, this study chose to apply an in-depth analysis to find the possibility of other types and their economic positions. The reconnaissance survey found several indications of mineralization, such as in the area of Sumbersari in Kaligesing District and Wadas in Loano District. These places are located within the target areas that have high lineament density.

The results of the field observations in Kaligesing showed that the dominant lithology was andesite 
and dioritic rocks as windows on the river. This rock unit is heavily affected by the geological structure trending N-NE and N-NW. The structure is followed by the presence of argillic alteration and silicification (Figure 11a), which indicates the existence of a working hydrothermal system. In Loano, only strong fractured rocks were found, which are followed by argillic alteration and local silicification and boulder of weakaltered rocks. In this block, we have not found the good outcrop yet. However, the limited outcrop and float characters indicate the presence of a hydrothermal system at low temperatures and $\mathrm{pH}$. This system can be part of the large Kaligesing system because it is still in the same ancient volcanic complex system. In Wadas, the research only found limited float of silicified rock far from the target area. The target area had a morphological anomaly that was identified from satellite imagery and the topographic features in SRTM analysis.

This research acquired some interesting data in Kaligesing, namely:

a) In Sumbersari Hamlet, Kaligono Village, Kaligesing District, Purworejo, dioritic rocks were discovered. These rocks altered to several hydrothermal alteration group, such as epidote-sericitecarbonate, and biotite- actinolite-chlorite and followed by porphyry type veins. The hydrothermal alteration continuos along $300 \mathrm{~m}$ outcrop, and then enveloped by andesite breccia as pyroclastic product of Gadjah Mountain.

b) The mineralization was shown by the occurrences of sulfides that were megascopically described as chalcopyrite vein filling and/or fractures and dissemination of pyrite. The mineralization is also associated with the presence of $\mathrm{A}, \mathrm{AB}$ and $\mathrm{C}$ veins (Figure 11b-c). The potential of this area lies in the presence of porphyry and epithermal systems.

\section{Conclusion}

The Lineament Density Analysis (LDA) shows an anomalous pattern in Kulon Progo. This pattern was combined with geological parameters, such as structural geology, lithology, and the boundaries of the volcano system. The anomaly illustrates the presence of new mineralization in the field, as evidenced by a simple field check, i.e., geological reconnaissance survey.

The area of mineralization was identified in the proximal to the central facies of the volcano. It has some weak zones (represented by a high density of lineament) that are commonly caused by tectonics. The type of mineralization interpreted as epithermal related porphyry type, but this conclusion still requires further field data confirmation. The economic potential of gold-copper in Kulon Progo is low to medium, but occurences of the associated systems in the subsurface, i.e., porphyry $\mathrm{Cu}-\mathrm{Au}$, may increase potential.

The target area of this research can be developed for other locations, provided that the other supporting data, such as lithological anomalies, outcrops, and geochemical data, are available. Based on the results of this study, detailed research of geological mapping, geophysics, and geochemical exploration are expected. Further research can provide the basis for developing the potential of Kulon Progo Mountains.

\section{Acknowledgment}

The author(s) would like to thank the management of ITNY for their research funding and fellow academic colleagues for the discussion.

\section{References}

Abdullah, A., Akhir, J. M. \& Abdullah, I. (2010). Automatic Mapping of Lineaments Using Shaded Relief Images Derived from Digital Elevation Model (DEMs) in the Maran - Sungai Lembing Area, Malaysia, Electronic Journal of Geotechnical Engineering, 15(6), pp. 949-958. doi: 10.1039/CS9962500401.

Ansori, C. \& Hastria, D. (2013). Studi Alterasi dan Mineralisasi disekitar gunung Agung, Kabupaten Kulon Progo Purworejo, Buletin Sumber Daya Geologi, 8, pp. 75-86.

Barianto, D. H., Kuncoro, P. \& Watanabe, K. (2010). The Use of Foraminifera Fossils For Reconstructing The Yogyakarta, SE Asian Appl. Geol, 2(2), pp. 138-143.

Bronto, S. (2013). Geologi Gunung Api Purba. Badan Geologi. Hadi, M. P. (2010). Application Integration Methods On Landsat ETM+ to Determine Earthquake Potentials in Palu Graben, Indonesian Journal of Geography, 42(1), pp. 91-104.

Harjanto, A. (2011). Vulkanostratigrafi Di Daerah Kulon Progo Dan Sekitarnya, Daerah Istimewa Yogyakarta, Jurnal Ilmiah MTG, 4(8), pp. 1-18.

Harjanto, A., Suparka, E., Asikin, S. \& Yuwono, Y. S. (2006) Magmatic related to hydrothermal alteration in Kulon Progo, Central Java, Indonesia, in Kusumayudha, S. B., Sutarto, Hartono, H. G., Rao, N., Purwanto, H. S., Sakundarini, N., Danisworo, C., Limaye, S. D., and Balderner, W. (eds.) International Interdisciplinary Conference Volcano International Gathering. Yogyakarta: Planetearth.

Harjanto, A., Suparka, E., Asikin, S. \& Yuwono, Y. S. (2009). Endapan Emas Epitermal Berumur Neogen Di Daerah Kulon Progo Dan Sekitarnya, Daerah Istimewa Yogyakarta, Jurnal Ilmiah Teknologi Mineral, 22(2), pp. $1-17$.

Hartono, H. G. (2010). Peran Paleovolkanisme Dalam Tataan Produk Batuan Gunung Api Tersier di Gunung Gajahmungkur, Wonogiri, Jawa Tengah. University Padjadjaran.

Haryono, E., Widartono, B. S., Lukito, H. \& Kusumayuda, S. B. (2016). A comparison of lineament and fracture trace extraction from LANDSAT ETM+ panchromatic band and panchromatic aerial photograph in Gunungsewu karst area, Java-Indonesia, in IOP Conference Series: Earth and Environmental Science. IOP Publishing, p. 12026.

Hubbard, B. E., Mack, T. J. \& Thompson, A. L. (2012) Lineament Analysis of Mineral Areas of Interest in Afghanistan. USGS Open-. Reston, Virginia: U.S. Geological Survey. Available at: http://pubs.usgs.gov/ of/2012/1048.

Idrus, A., Warmada, i wayan, Satriadi \& Nabila, aji shadji (2014). Mineralisasi Emas di Kalisat, Magelang, Jawa Tengah : Prospek Emas Tipe Epitermal Sulfidasi Rendah di Pegunungan Kulon Progo -Menoreh, in Annual Engineering Seminar 2014. Yogyakarta: Fakultas Teknik 
UGM, p. D-35.

Idrus, A., Warmada, I. W. \& Putri, R. I. (2013). Mineralisasi Emas di gunung Gupit, Magelang, Jawa Tengah: Sebuah Penemuan Baru Prospek Emas Tipe Ephitermal Sulfidasi Tinggi pada Rangkaian Pegunungan Kulon ProgoMenoreh.

Leary, D. W. O., Friedman, J. D. \& Pohn, H. A. (1976). Geological Society of America Bulletin Lineament, linear, lineation : Some proposed new standards for old terms, Geological Society of America Bulletin, 87(10), pp. 1463-1469. doi: 10.1130/0016-7606(1976)87<1463.

Maryono, A., Setijadji, L. D., Arif, J., Harrison, R. \& Soeriaatmadja, E. (2012). Gold, Silver and Copper Metallogeny of the Eastern Sunda Magmatic Arc Indonesia, in Proceeding of Banda and Eastern Sunda Arcs 2012 MGEI Annual Convention, pp. 26-27.

Pambudi, D., Winarno, T. \& Aribowo, Y. (2018). Geologi dan Mineralisasi Logam Daerah Sangon, Kokap, Kulon Progo, Daerah Istimewa Yogyakarta, Jurnal Geosains dan Teknologi, 1(2). doi: 10.14710/jgt.1.2.2018.74-80.

Pramumijoyo, P., Idrus, A., Warmada, I. W. \& Yonezu, K. (2017). Geology , Geochemistry and Hydrothermal Fluid Characteristics of Low Sulfidation Epithermal Deposit in the Sangon Area, Kokap, Special Region of Yogyakarta, Journal of Applied Geology, 2(1), pp. 48-58. doi: $10.22146 /$ jag. $30 . .$.

Prasetyo, L. A., Fadlin, Siswandi, Anggoro, W. T. \& Oktaviany, A. (2017). Pre-Eliminary Study High Sulphidation Epithermal Gold And Possibility Porphyry System In The Southern Part Of Kulon Progo Dome- HargerejoBagelen- Purworejo, in JCM HAGI-IAGI-IAFMI-IATMI

Rahardjo, W., Sukandarrumidi \& Rosidi, H. (1995) Yogyakarta Sheet Geological Map scale 1:100.000. Bandung: Geological Research and Development Center.

Setijadji, L. D., Kajino, S., Imai, A. \& Watanabe, K. (2006) Cenozoic island arc magmatism in Java Island (Sunda Arc, Indonesia): Clues on relationships between geodynamics of volcanic centers and ore mineralization, Resource Geology, 56(3), pp. 267-292. doi: 10.1111/ j.1751-3928.2006.tb00284.x.
Setijadji, L. D. \& Maryono, A. (2012). Geology and Arc Magmatism of the Eastern Sunda Arc, Indonesia," in Proceeding of Banda and Eastern Sunda Arcs 2012 MGEI Annual Convention, pp. 26-27.

Sillitoe, R. H. (2010). Porphyry Copper Systems," Economic Geology, 105, pp. 3-41.

Smyth, H. R., Hall, R. \& Nichols, G. J. (2008). Cenozoic volcanic arc history of East Java, Indonesia: The stratigraphic record of eruptions on an active continental margin, Geological Society of America Special Papers, 436(10), pp. 199-222. doi: 10.1130/2008.2436(10).

Soeria-Atmadja, R., Maury, R. C., Bellon, H., Pringgoprawiro, H., Polve, M. \& Priadi, B. (1994). Tertiary magmatic belts in Java, Journal of Southeast Asian Earth Sciences, 9(12), pp. 13-27. doi: 10.1016/0743-9547(94)90062-0.

Syafri, I., Budiadi, E. \& Sudradjat, A. (2013). Geotectonic Configuration of Kulon Progo Area, Yogyakarta Konfigurasi Tektonik Daerah Kulon Progo, Yogyakarta, Indonesian Journal of Geology, 8(4), pp. 185-190.

Thannoun, R. G. (2013). Automatic Extraction and Geospatial Analysis of Lineaments and their Tectonic Significance in some areas of Northern Iraq using Remote Sensing Techniques and GIS, International Journal of Enhanced Research in Science Technology and Engineering, 2(2), pp. 1-11.

Verdiansyah, O. (2015). Aplikasi Lineament Density Analysis Untuk Prospeksi Mineral Ekonomis: Studi Kasus Pada Daerah Cikotok, Pongkor dan Lebong Tandai, in Prosiding Nasional Rekayasa Teknologi Industri dan Informasi XI (ReTII). Yogyakarta: STTNAS, pp. 105112.

Verdiansyah, O. (2017). Aplikasi Lineament Density Analysis Untuk Membatasi Pola Kaldera Purba Godean, Jurnal Teknologi Technoscientia, 9(2).

Widagdo, A., Pramumijoyo, S. \& Harijoko, A. (2018). The Morphotectono-Volcanic of Menoreh-Gajah-Ijo Volcanic Rock In Western Side of Yogyakarta-Indonesia, Journal of Geoscience, Engineering, Environment, and Technology, 3(3), p. 155. doi: 10.24273/jgeet.2018.3.3.1715. 